\title{
Economic Output and Government Expenditures: Applicability of Wagner's Law in Jordan
}

\author{
Ihab Khaled Magableh ${ }^{1}$, Nabeel Sawalha ${ }^{2} \&$ Mohammad I. Elian ${ }^{2}$ \\ ${ }^{1}$ Arab Planning Institute, Kuwait \\ ${ }^{2}$ College of Business Administration, Gulf University for Sciences and Technology, Kuwait \\ Correspondence: Nabeel Sawalha, College of Business Administration, Gulf University for Sciences and \\ Technology, Kuwait. Tel: 965-2530-7341. E-mail: Sawalha.n@gust.edu.kw
}

Received: August 8, 2014

doi:10.5539/ijef.v6n12p244
Online Published: November 25, 2014

URL: http://dx.doi.org/10.5539/ijef.v6n12p244

\begin{abstract}
We examine the applicability of Wagner's Law in Jordan by testing the relationship between economic growth and governmental expenditures, then measuring the effectiveness of the output growth in reducing the governmental budget deficit, and followed by exploring the dependence of governmental expenditure on the governmental domestic revenues and foreign grants over the period 1980-2013. Following Peacock and Wiseman (1979) modeling to test for Wagner's Law, It was found that the elasticity of the real expenditures with respect to the real GDP is positive and greater than 1, which conforms and validates Wagner's Law in the case of the real governmental expenditures and its components. Furthermore, the real current expenditures had the highest elasticity, indicating that their responsiveness to the real GDP is greater than that of the real capital expenditures. We also found that the elasticity of the real total governmental revenues and grants is positive and greater than 1 , but less than the elasticity of governmental revenues. However, the elasticity of the real local revenues, the real income tax revenues, and the real taxes on domestic transactions are all positive and greater than 1. Interestingly, we found that the elasticity of the real foreign trade revenues is, while positive, too low and less than 1 . This fact explains the relative low value of the elasticity of the real total governmental revenues with respect to the real GDP since the real foreign trade taxes represent the major part of the local revenues.
\end{abstract}

Keywords: economic growth, Wagner's law, governmental expenditures, budget deficit, governmental revenues, real GDP

\section{Introduction}

The Jordanian economy is among the smallest in the Middle East. It suffers from insufficient supplies of water (Jordan is the fourth poorest country worldwide), natural resources and a lack of oil and gas, underlying the government's heavy reliance on foreign assistance. The lack of sufficient financial and non-financial resources, in addition to regional and international political and economic disturbances (e.g., Iraq, Syria, and Egypt) gives rise to numerous challenges at both the micro and macro levels. These challenges include a high poverty rate $(18 \%$ in 2013), persistent unemployment (13\% in 2013), a high level of inflation (5.6\% in 2013), a large budget deficit (JD1946.3 million in 2013), a trade balance deficit (JD8143.6 million in 2013), and a chronic public debt (JD19096.5 million in 2013). In addition, the Jordanian economy suffers from structural imbalances that restrict the success of governmental policies. These imbalances are manifested in Jordan's demographic structure sources and uses of GDP, governmental revenues, governmental expenditures and geographical and commodity distribution of exports and imports (Magableh et al., 2010; Mutable, 2009a; Central Bank of Jordan (CBJ), 2013). In the last three decades, successive governments have implemented significant economic reform programs, such as opening the trade regime, privatizing many state-owned companies, changing the tax law, enhancing the business environment, and eliminating fuel subsidies. These reforms have spurred economic growth by attracting foreign direct investment, increasing inbound remittances, and creating jobs. However, economic growth could not solve all of the challenges discussed above, nor stop their growth.

Among the major challenges that require more attention and analysis are those related to the public finance sector: increasing governmental expenditures, the continuation of the budget deficit, governmental reliance on external sources of fund (grants and loans), and the structural imbalances in both governmental expenditures and revenues. The seriousness of the governmental budget related problems is due to their extreme impact on the government's 
ability to undertake its economic and social duties, their impact on social welfare, and their negative impact on the financial standing of the government. To alleviate the negative impacts of these challenges, there needs to be a unification of efforts of the government and the private sector. Moreover, researchers can play a major role in diagnosing these problems, suggesting applicable solutions and leading the unification efforts. However, very little diagnostic research has been conducted in order to dissect the specificities of governmental budget-related problems. Economic analysts agree that the size of the Jordanian budget is too big in relative terms $(29.7 \%$ of the GDP in 2013). The reason for these high governmental expenditures is that foreign and Arab grants were historically easy to secure. These grants allowed governments to expand beyond the limits dictated by the small size of the domestic economy and the limited local resources. Ways and means to increase revenues have almost been exhausted; no more taxation is acceptable or feasible under the current circumstances. The ratio of tax revenues exceeded $60 \%$ of the total governmental expenditures over the last decade. It is imperative to shift our attention to reducing public spending, or at least allowing spending to rise at a lower rate than the current economic growth rate. However, public spending normally rises annually due to factors such as inflation, which leads to more money to buy the same goods and services, and population growth and the constant demand for more public services to accommodate more people, especially when it comes to infrastructure, public health, and education (Case \& Fair, 2008). In summary, governmental expenditures in Jordan have been increasing faster than revenues, resulting in a chronic and increasing deficit. Accordingly, the government has chosen to resort to borrowing to bridge the gap. In the meantime, new ways appear to increase spending.

The growth of governmental expenditures has gained significant attention in both developed and developing countries, but not in Jordan. All efforts are focused on financing the deficit with little attention paid to analyzing the relationship between the governmental budget and other economic variables such as output. Accordingly, the relationship between output growth and the public finance sector needs to be closely analyzed. This paper examines the relationship between economic growth and governmental expenditures, measures the effectiveness of output growth in reducing the governmental budget deficit, and explores the dependence of governmental expenditures on the governmental domestic revenues and foreign grants. More importantly, it examines the applicability of Wagner's Law in Jordan. The paper consists of five sections. The first section is the introduction; section two presents the literature review, section three analyzes the output and governmental budget in Jordan, and section four presents the model, the estimation methods and results. Finally, section five summarizes the results and recommendations of the study.

\section{Literature Review}

There is a consensus that a persistently large budget deficit is a major problem for a government and the economy. First, the budget deficit has to be financed by issuing new governmental debt to domestic or external investors. In a world where financial capital flows freely between countries, it can be relatively easy to finance a deficit (Gordon, 2006). However, when the budget deficit rises to a high level, the government may have to offer higher interest rates to attract sufficient lenders. This situation in turn has a negative effect on economic growth. Secondly, a high level of governmental borrowing adds to the accumulated public debt. This fact means that the government has to spend more each year in debt-interest payments. Finally, reducing the budget deficit can be achieved by either reducing governmental expenditures or by imposing more taxes and fees. If a larger budget deficit leads to higher interest rates and taxation in the medium term and thereby has a negative effect on growth in household consumption and investment spending, then a process of 'fiscal crowding-out' is said to be occurring (Gordon, 2006). In light of the seriousness of the budget deficit, it becomes necessary to analyze the causes and suggested solutions to this problem. Such a process requires following up the development of public revenues and expenditures. It also requires measuring the impact of economic growth on both the development of public revenues and expenditures. This process helps to determine whether higher economic growth rates make the governmental budget better off or worse off. In 1883, the German economist Adolph Wagner was the first person to observe the existence of a relationship between economic growth and public expenditures; this relationship was later formulated as "Wagner's Law" (Verma \& Arora, 2010). Wagner's Law implies that the growth in public expenditures is stimulated by economic growth. This fact implies that the governmental expenditures ratio with respect to the GDP increases with increasing GDP, which means that the elasticity of governmental expenditures to GDP is more than unity (Verma \& Arora, 2010). Wagner identified three main factors for increased governmental expenditures. First, the administrative and protective role of the government increases as a country's economy develops. Second, with the expansion of the economy, governmental expenditures on "cultural and welfare" have risen, particularly with respect to education and health. Wagner implicitly assumed that the income elasticity of demand for public goods is more than unity. Finally, technological progress of industrialized nations requires the government to undertake certain economic services that the private sector is wary of being responsible for (Khan, 
1990). Wagner's Law has attracted the attention of many researchers and different interpretations. While the law has been supported by many studies (e.g., Gyles, 1991; Oxley, 1994; Dritsakis \& Adamopoulos, 2004; Sztbyer, 2001), it has not been without criticism. The law did not find support in many empirical studies (e.g., Henrekson, 1993; Courakis et al., 1993; Hondroyiiannis \& Papapetrou, 1995). Some studies used different versions of the law for a specific country but some versions support the law and others exhibit contradictory results (e.g., Man, 1980; Chletsos \& Kollias, 1997).

Peacock and Wiseman (1967) suggested that public spending may increase, but not in the way that Wagner hypothesized. For example, the empirical relevance of Wagner's Law has been investigated and given unambiguous support by Oxley (1994); Chletsos and Kollias (1997) argue that support for Wagner's Law could be found only for selected items of governmental expenditures. Ram (1987) has reported that while some time-series studies support Wagner's hypothesis, cross-sectional studies fail to provide such support. There have been single-country (e.g., Henrekson, 1993 (Sweden); Murthy, 1993 (Mexico); Khan, 1990 (Pakistan); Mohsin et al., 1992 (India); Afxentiou \& Serletis, 1991 (Canada); Park, 1996 (Korea); Nomura, 1995 (Japan)), cross-country (e.g., Ram, 1987; Mohsin et al., 1995) studies using 115 and 20 countries, respectively. Anwar et al. (1996) studied 88 countries, and the Bohl (1996) study was limited to G-7 countries. These studies used different approaches to empirically examine Wagner's Law ranging from traditional econometric techniques to more recent time-series econometrics methods. The use of diverse approaches has produced different results (Afzal \& Abbas, 2010). Wagner's Law is based on a simple positive relationship between public expenditures and economic growth. Wagner's Law has been criticized for its vague nature. Gandhi (1971) noted that the imprecise nature of Wagner's Law has led to the development of different versions of Wagner's Law. There are at least six versions of Wagner's Law that have been empirically investigated since the 1960s. However, there is no decisive standard to decide which one of the versions is the most suitable. Afzal and Abbas (2010) found the most common six functional forms of the law cited in the literature.

Moving to highlight the application of Wagner's Law to developing countries, Afzal and Abbas (2009) used traditional as well as time-series econometric techniques to reinvestigate the application of Wagner's Law to the Pakistani economy (1960-2007). These authors explored the relationship between aggregate governmental expenditures and the per capita GDP. The results indicated that there was no long-term relationship between aggregate expenditure and income, as well as between disaggregated expenditure and income. The same relationship does not hold when fiscal deficit and population growth are considered. However, the results showed that there is no causality between income and public spending. In addition, there is a unidirectional causality between fiscal deficit and governmental expenditures, as well as between income and fiscal deficit. Finally, Afzal and Abbas (2009) indicated that economic development measured by real GDP per capita causes population growth. Providing more insights into this issue and particularly in the case of Pakistan, Iqbal and Siddiqi (2010) examined the relationships among governmental expenditures, population, economic growth, and export. Population and exports have a significant correlation with governmental expenditures. With increases in population and export, governmental expenditures increase. However, it has been indicated that Wagner's Law does not hold since GDP has a positive and significant relationship with governmental expenditures. Iqbal and Siddiqi (2010) concluded that the increase in public spending in the case of Pakistan does reliant on economic growth as Wagner's Law state. As a result, the public spending is the result of many assessments in light of changing economic circumstances. Moreover, Akitoby et al. (2006) investigated the short- and long-term behavior of governmental expenditures with respect to output in a large group of developing countries (51 countries). They found evidence that this is consistent with the existence of cyclical ratcheting and voracity in governmental expenditures in developing countries, resulting in a tendency for governmental expenditures to increase over time. They concluded that the short- and long-term elasticity of capital spending in relation to GDP is relatively high, indicating that governments expand their capital budgets proportionally more during upswings, or cut their budget outlays disproportionally during economic downturns. In Greece, efforts to test for the validity of Wagner's Law yielded different results. For example, Georgeakopoulos and Loizides (1994) andHondroyiiannis and Papapetrou (1995) found no supportive evidence for Wagner's Law in Greece. On the other hand, Dritsakis and Adamopoulos (2004) and Sideris (2007) found that the law is valid, while Chletsos and Kollias (1997) and Loizides and Vamvoukas (2005) found mixed results across different versions of the law. While the validity of Wager's Law has been studied in both developed and developing countries, no studies has been conducted in Jordan. More importantly, while it is important to study how economic growth affects governmental expenditures (the validity of Wagner's Law), it is critical to examine the impact of economic growth on governmental revenues. Furthermore, a clearer analysis requires examining the impact of GDP on the individual components of governmental expenditures and the components of governmental revenues. By doing so, a comprehensive diagnosis can be achieved. If the impact of GDP growth on governmental revenues is found to be higher than on governmental 
expenditures, then it can be concluded that economic growth makes the governmental budget better off. On the other hand, if the impact of GDP growth on governmental revenues is found to be less than on governmental expenditures, then it can be said that economic growth aggravates the governmental budget deficit.

\section{Output and Governmental Budget in Jordan}

The Jordanian economy has been affected by numerous forces and events on local, regional and global levels that have had profound impacts in the last decades. These forces and events include the first Gulf War in Iraq, the repercussions of the Jordanian Dinar devaluation in 1989, the second Gulf War in Iraq, birds and pig flus, the 9/11 attacks, the economic financial crisis, the Arab Spring developments in Egypt, Libya, Tunisia, and finally the new political instability and repercussions of the crisis in Syria and Iraq. For example, the Syrian crisis led to the displacement of millions of Syrians to Jordan, which added an additional burden to the governmental budget because of the high costs of dealing with the ongoing displacement of Syrian people (an estimated $0.7 \%$ of the GDP). All the above mentioned these factors have led to a poor performance of the public finance sector in general and the general budget in particular, forcing the need for external support to help defray the current and increasing burden. The fiscal deficit, including foreign grants, has increased to a record level standing at $8.2 \%$ of the GDP in 2012 and $5.5 \%$ in 2013. The study of the performance of the economy in general, the GDP growth rates, and developments in public finance sector are critical for increasing our understanding of the relationship between the GDP and public finance sector.

During the last past three decades, the Jordanian economy achieved reasonable GDP growth rates at current and fixed prices. This growth was due to economic reforms that were implemented by consequent governments in order to spur economic growth and reduce the severity of the public budget deficit. GDP at current prices increased from JD1164.8 million in 1980 to JD 23851.6 million in 2013 at an average annual growth rate of $10.3 \%$. These rates are artificially inflated because of the high inflation rates. For example, in 1989 the inflation rated reached $15.5 \%$. The highest growth rate of $28.5 \%$ - was achieved in 2008 due to the world financial crisis and the unprecedented rate of inflation of 19.8\%. Real GDP (1994 prices) increased from JD 2818.1 million in 1980 to JD 10812.8 million in 2013 at an average annual growth rate of $4.6 \%$. Such growth rates are acceptable in light of the scarcity of financial and natural resources, in addition to the chronic government budget deficit and growing public debt. Table 1 lists developments of GDP and inflation rates during the period 1980-2013. The table shows a huge gap between real and nominal GDP growth rates in all periods, but the gap was wider during the period 2005-2009 due to the implications and consequences of the global financial crisis in 2008. The table also clearly shows a negative real GDP growth rate and modest GDP growth rate during the period 1985-1989. The inflation rate, measured by the percentage change of the GDP deflator, was the highest in 2005-2009, where the inflation rate measured by Consumer Price Index (CPI) was the highest in 1990-1994.

Table 1. GDP growth rates and inflation rates (1980-2013)

\begin{tabular}{ccccc}
\hline Year & GDP Current Prices & GDP Fixed prices & Inflation Rate $\% \Delta$ GDP Deflator & Inflation Rate $\% \Delta$ CPI \\
\hline $1980-1984$ & $14.4 \%$ & $7.5 \%$ & 6.5 & 7.0 \\
$1985-1989$ & $5.0 \%$ & $-0.8 \%$ & 6.1 & 7.0 \\
$1990-1994$ & $12.6 \%$ & $5.0 \%$ & 7.2 & 7.1 \\
$1995-1999$ & $5.8 \%$ & $3.6 \%$ & 2.2 & 3.1 \\
$2000-2004$ & $7.0 \%$ & $5.6 \%$ & 1.3 & 1.8 \\
$2005-2009$ & $16.1 \%$ & $7.4 \%$ & 8.1 & 5.6 \\
$2010-2013$ & $9.0 \%$ & $2.6 \%$ & 6.2 & 5.0 \\
\hline
\end{tabular}

Source: Central Bank of Jordan (CBJ).

The Government of Jordan (GOJ) has run a budget deficit in most years since 1980. The size of the public and current budget deficits/surplus varies according to the government's revenues and spending annual growth rates. The total deficit increased from JD 38.8 million in 1980 to JD 1307.2 million in 2013, including grants, and to JD 1946.3 million excluding grants. In 2013, the deficit-to-GDP ratio was 5.5\% including grants and $8.2 \%$ excluding grants. The self-reliance indicator, in consequence, as measured by the coverage ratio of domestic revenues to current expenditures, shows the inability of local revenues to cover operating expenses, except for few years. Thus, the current deficit increased from JD 110 million in 1980 to JD 931.3 million in 2013 (3.9\% of the GDP). Table 2 shows a dramatic increase in the total and current deficits during all periods, except for the beginning of the 1990s (1990-1994). The successive increase in the average annual deficits can explain the successive increase in the total 
public debt during the same period. Previous figures confirm the government's needs to resort to domestic and external loans or expect more grants in order to reduce the growing budget deficits.

Table 2. Average annual deficits (1980-2013)

\begin{tabular}{lcc}
\hline Year & Total Deficit/surplus & Current Deficit/Surplus \\
\hline $1980-1984$ & -29.76 & -79.86 \\
$1985-1989$ & -50.34 & -107.7 \\
$1990-1994$ & 39.32 & 40.50 \\
$1995-1999$ & -205.02 & -63.04 \\
$2000-2004$ & -221.42 & -297.52 \\
$2005-2009$ & -676.5 & -182.38 \\
$2010-2013$ & -1391.02 & -1109.17 \\
\hline
\end{tabular}

Source: Central Bank of Jordan (CBJ).

Prior to 1992, total governmental revenues or "revenues and receipts" (as referred to by the CBJ) were classified into domestic revenues, external aids, loans repaid, external loans, and domestic loans. From the year 1992 on, governmental revenues was referred as "total revenues and grants." The government's revenues and grants continuously increased during the period 1980-2013 except in 1992, 2009, and 2011. The revenues and grants increased from JD 525 million in 1980 to JD 5758.2 million at an average annual growth rate of $8.3 \%$. The majority of the revenue came from local sources. Local revenues increased from JD 226.1 million in 1980 to JD 5119.1 million in 2013 at an average annual growth rate of $11.3 \%$. The local revenue to total revenue ratio ranged between about $43.0 \%$ in 1980 to $93.5 \%$ in 2012 . In 2013 , about $88.2 \%$ of the revenue was collected from local sources $(21.5 \%$ of the GDP). In the meantime, grants increased from JD 209.3 million in 1980 to JD 639.1 million in $2013(2.7 \%$ of the GDP) at an average annual growth rate of $15.4 \%$. The figures discussed above show that the GOJ has been relying heavily on foreign grants. This fact may indicate the tendency of the government to increase the ratio of local sources in order to increase stability. On the other hand, governmental expenditures increased from JD 563.2 million in 1980 to JD 7065.4 million in 2013 (29\% of the GDP) at an annual growth rate of 8.4\%. Current expenditures increased from JD 336.1 million in 1980 to JD 6050.4 million in 2013 (25.4\% of the GDP) at an annual growth rate of $9.5 \%$. In the meantime, capital expenditures increased from JD 227.1 million in 1980 to JD 1015 million in 2013 (4.3\% of the GDP) at an average annual growth rate of $7.4 \%$. In summary, Table 3 lists the average annual growth rates of governmental revenues and expenditures. This table shows that expenditures grew faster than revenues during the periods 1995-1999 and 2005-2009, while revenues grew faster during the other periods. The data also show a notable fluctuation in the average annual growth rates of all revenues and expenditures.

Table 3. Average annual growth rates of governmental revenues and spending (1980-2013)

\begin{tabular}{|c|c|c|c|c|c|c|}
\hline Year & Gov. Revenues & Local Revenues & Foreign Grants & Gov. Expenditures & Current Expenditures & Capital Expenditures \\
\hline 1980-1984 & $7.9 \%$ & $17.7 \%$ & $-10.5 \%$ & $7.0 \%$ & $8.8 \%$ & $4.1 \%$ \\
\hline 1985-1989 & $10.2 \%$ & $6.5 \%$ & $26.5 \%$ & $9.1 \%$ & $9.0 \%$ & $11.0 \%$ \\
\hline 1990-1994 & $7.7 \%$ & $19.3 \%$ & $5.4 \%$ & $7.7 \%$ & $10.1 \%$ & $3.2 \%$ \\
\hline 1995-1999 & $3.5 \%$ & $3.0 \%$ & $8.6 \%$ & $5.2 \%$ & $6.3 \%$ & $1.2 \%$ \\
\hline $2000-2004$ & $10.5 \%$ & $7.9 \%$ & $24.8 \%$ & $9.4 \%$ & $7.8 \%$ & $16.5 \%$ \\
\hline 2005-2009 & $9.7 \%$ & $14.8 \%$ & $-1.8 \%$ & $13.7 \%$ & $14.3 \%$ & $15.0 \%$ \\
\hline 2010-2013 & $6.6 \%$ & $5.3 \%$ & $61.3 \%$ & $4.4 \%$ & $7.5 \%$ & $-2.3 \%$ \\
\hline
\end{tabular}

Source: CBJ.

Local revenues refer to tax revenues (e.g., income tax, taxes on domestic transactions, and taxes on foreign trade) and non-tax revenues (e.g., licenses, fees, interests and profits, and pension contributions). In 2013, tax revenues were $71.8 \%$ of local revenues and non-tax revenues were $18.2 \%$ of local revenues. Taxes on income and profits constituted about $18.7 \%$ of tax revenues (11.8\% of total revenues), while taxes on international trade and transactions constituted $8.9 \%$ of tax revenues (5.6\% of total revenues). Taxes on goods and services constituted $69.3 \%$ of tax revenues and $44 \%$ of total revenues. 
Referring back to the paper's objectives, which focused on exploring the relationship between GDP and governmental expenditures and revenues growth rates, Figure 1 shows the average annual growth rates of governmental revenues and spending during the time period 1980-2013. This figure shows that GDP grew faster than governmental expenditures and revenues in all periods except for 1985-1989 and 2000-2004. The figure initially supports the expectations about the existence of a positive relationship between economic growth and growth in governmental expenditures, which is empirically tested in this paper.
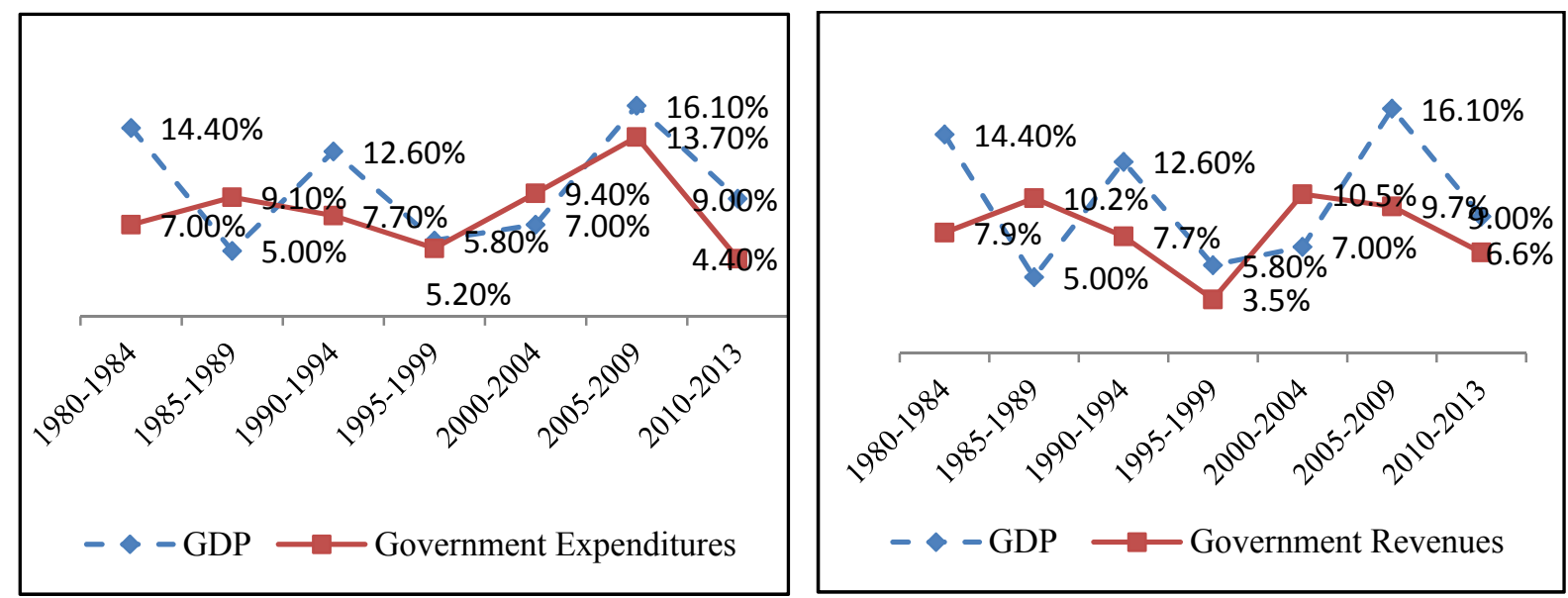

Figure 1. Average annual growth rates of GDP and governmental revenues and expenditures

\section{Model and Estimation Results}

There are at least six versions of Wagner's Law that have been empirically investigated and tested for their validity since the 1960s. However, there is no decisive standard to determine which one of the versions is the most suitable and persuasive for testing Wagner's Law. Wagner's Law states that governmental activity increases as economies grow, with the pace of increase differing for different branches of governmental expenditures (Wagner, 1911). As discussed above, researchers used several versions to empirically test for the validity of Wagner's Law. Gupta (1967) used real per capita governmental expenditures as a function of real per capita output, as shown in formula (1). If the elasticity is greater than unity, one can confirm the validity of the law. Musgrave (1969) used the share of real governmental expenditures to output as a function of real per capita output, as shown in formula (2), where $G$ refers to governmental expenditures, GDP and RGDP refer to nominal and real GDP, respectively, and N refers to the population number. The requirement to support Wagner's hypothesis is that the elasticity of governmental expenditures with respect to the real output per capita exceeds zero, which means that $\frac{G}{G D P}$ increases as $\frac{R G D P}{N}$ increases.

$$
\begin{gathered}
\frac{G}{N}=f\left(\frac{G D P}{N}\right) \\
\frac{G}{G D P}=f\left(\frac{R G D P}{N}\right)
\end{gathered}
$$

Pryor (1969) used real governmental consumption expenditures as a function of real output, as shown in formula (3). The validity of Wagner's Law requires that the elasticity of governmental consumption with respect to income exceed unity.

Goffman and Mahar (1971) used real governmental expenditures as a function of real per capita output, as shown in formula (4). The validity of the law implies elasticity greater than 1.

$$
\begin{gathered}
G C=f(G D P) \\
G=f\left(\frac{G D P}{N}\right)
\end{gathered}
$$

Peacock and Wiseman (1979) modeled public spending versus income, as shown in formula (5). The validity of Wagner's Law requires that the elasticity of governmental expenditures with respect to output is greater than unity. Mann (1980) discussed a closely related specification of the Peacock and Wiseman (1979) modeling. Mann used the share of governmental expenditures in the total output as a function of the real output, as shown in formula (6). To confirm the validity of the law, Mann assumed that the estimated elasticity in formula (3) must be greater than unity and elasticity of formula (4) must be positive. 


$$
\begin{gathered}
G=f(G D P) \\
\frac{G}{G D P}=f(G D P)
\end{gathered}
$$

This part of the study aims to estimate the elasticity of real governmental expenditures with respect to the real GDP (in order to eliminate the inflation effect, real terms are used) during the period 1980-2013. This analysis follows the work of Peacock and Wiseman (1979), as shown in formula (7):

$$
\log R G=\alpha 0+\alpha 1 \log R G D P, \alpha 1>1
$$

where RG refers to governmental expenditures at constant prices and RGDP is the real GDP. Moreover, for a deeper discussion and understanding of the impact of economic growth on capital and current expenditures separately, the elasticity of the real current expenditures (RCURG) and real capital expenditures (RRCAPG) with respect to RGDP are also estimated, as shown in formulas (8) and (9):

$$
\begin{gathered}
\log R C U R G=\beta 0+\beta 1 \log R G D P, \beta 1>1 \\
\log R C A P G=\delta 0+\delta 1 \log R G D P, \delta 1>1
\end{gathered}
$$

Prior to the estimation process, we tested for causality between all dependents variables and explanatory variables; we also performed a cointegration test for all models. In order to avoid indignity problems and obtain more accurate results, the General Method of Moment (GMM) estimation method was used. More precisely, the GMM estimators developed for dynamic models of panel data were used to avoid spurious conclusions and to add robustness and inferences correction to our results, which can be attained by adding a moment condition under the assumption that past value of the explanatory variables is uncorrelated with the error term, hence avoiding spurious results.

The first and second lags of the explanatory variable (LOG(RGDP(-1)) LOG(RGDP(-2)) were used to as instrumental variables. The estimation results listed in Table.4.1 shows that elasticity of real governmental expenditures to changes in real GDP is greater than unity (1.779976) which support the validity of Wagner's law in case of Jordan. This means that governmental expenditures increase with economic growth but at higher rates. Results in table.4.2 and Table 4.3 support the validity of the law. The elasticity of the real current expenditures and real capital expenditures with respect to change in the real GDP were greater than unity, but the elasticity of the real current expenditures was higher. This fact means that economic growth has a greater impact on current expenditures since they are related to the operations conducted by the government during its activities in all markets and all sectors. Therefore, during expansion (positive growth rates), current expenditures grow faster than capital expenditures; the reverse scenario (negative growth rates) implies that real current expenditures regress faster than real capital expenditures.

Table 4.1. Dependent variable - real governmental expenditures (RG)

\begin{tabular}{lllll}
\hline Variable & Coefficient & Std. Error & t-Statistic & Prob. \\
\hline LOG(RGDP) & 1.78 & 0.11 & 16.05 & 0.00 \\
C & -7.65 & 0.99 & -7.73 & 0.00 \\
R-squared & 0.95 & Mean dependent var & & 7.59 \\
Adjusted R-squared & 0.96 & S.D. dependent var & & 0.70 \\
S.E. of regression & 0.15 & Sum squared resid & & 0.62 \\
Durbin-Watson stat & 0.31 & J-statistic & & 0.05 \\
\hline
\end{tabular}

Table 4.2. Dependent variable - real current expenditures (RCURG)

\begin{tabular}{lllll}
\hline Variable & Coefficient & Std. Error & t-Statistic & Prob. \\
\hline LOG(RGDP) & 2.01 & 0.152 & 13.22 & 0.00 \\
C & -9.96 & 1.355 & -7.35 & 0.00 \\
R-squared & 0.93 & Mean dependent var & & 7.31 \\
Adjusted R-squared & 0.93 & S.D. dependent var & & 0.80 \\
S.E. of regression & 0.20 & Sum squared resid & & 1.16 \\
Durbin-Watson stat & 0.25 & J-statistic & & 0.04 \\
\hline
\end{tabular}


Table 4.3. Dependent variable - real capital expenditures (RCAPG)

\begin{tabular}{lllll}
\hline Variable & Coefficient & Std. Error & t-Statistic & Prob. \\
\hline LOG(RGDP) & 1.38 & 0.05 & 27.25 & 0.00 \\
C & -5.79 & 0.44 & -13.01 & 0.00 \\
R-squared & 0.87 & Mean dependent var & & 6.15 \\
Adjusted R-squared & 0.86 & S.D. dependent var & & 0.50 \\
S.E. of regression & 0.18 & Sum squared resid & & 0.98 \\
Durbin-Watson stat & 1.04 & J-statistic & & 0.06 \\
\hline
\end{tabular}

In an attempt to demonstrate the effect of economic growth on governmental budget, we estimated the elasticity of governmental revenues with respect to economic growth using GMM and LOG (RGDP(-1)) and LOG(RGDP(-2)) as instrumental variables; see formula (10). The results of estimation are listed in Table 5.1.

$$
\log R R E V=\alpha 0+\alpha 1 \log R G D P
$$

The estimation results in Table 5.1 show that the elasticity of the real total governmental revenues and grants is positive (1.621123), but less than the elasticity of governmental expenditures. In light of the previous result, it appears that real GDP is not a key player in reducing the governmental budget deficit, especially during boom periods because higher real GDP growth rates lead to greater deficits; during bust periods, governmental budget deficits tend to decrease, ceteris paribus. However, this result requires further examination and explanation. To this end, we estimated the elasticity of the real domestic revenues, the real income tax revenues, the real foreign trade taxes, and the real non-tax revenues with respect to the real GDP. As expected, the elasticities were all positive. For example, Table 5.2 shows that the elasticity of local revenues was 1.914752 , but less than the elasticity of current expenditures (2.017267), which means that economic growth is not a key player in reducing the government's current budget deficit, especially during boom periods. However, this deficit may decrease during periods of bust times.

Table 5.1. Dependent variable - real governmental revenues (RREV)

\begin{tabular}{lllll}
\hline Variable & Coefficient & Std. Error & t-Statistic & Prob. \\
\hline LOG(RGDP) & 1.62 & 0.13 & 12.30 & 0.00 \\
C & -6.38 & 1.17 & -5.43 & 0.00 \\
R-squared & 0.92 & Mean dependent var & & 7.51 \\
Adjusted R-squared & 0.92 & S.D. dependent var & & 0.64 \\
S.E. of regression & 0.17 & Sum squared resid & & 0.88 \\
Durbin-Watson stat & 0.52 & J-statistic & 0.03 \\
\hline
\end{tabular}

Table 5.2. Dependent variable - real local revenues (RLREV)

\begin{tabular}{lllll}
\hline Variable & Coefficient & Std. Error & t-Statistic & Prob. \\
\hline LOG(RGDP) & 1.91 & 0.18 & 10.62 & 0.00 \\
C & -9.18 & 1.60 & -5.71 & 0.00 \\
R-squared & 0.89 & Mean dependent var & & 7.20 \\
Adjusted R-squared & 0.89 & S.D. dependent var & & 0.80 \\
S.E. of regression & 0.25 & Sum squared resid & & 1.94 \\
Durbin-Watson stat & 0.15 & J-statistic & & 0.01 \\
\hline
\end{tabular}

The results in Tables 5.3-5.6 show that the elasticity of all revenues is positive and greater than unity, except for the elasticity of foreign trade taxes, which was positive but less than unity. We found that the elasticity of Real Taxes on Domestic Transactions (RTDT) was the highest (2.689836), followed by the elasticity of Real Income Tax Revenues (RINCTAX), which was 1.959585. The elasticity of Real Non-Tax Revenues (RNONTAX) followed next, which was 1.122824 . 
Table 5.3. Dependent variable - real income tax revenues (RINCTAX)

\begin{tabular}{lllll}
\hline Variable & Coefficient & Std. Error & t-Statistic & Prob. \\
\hline LOG(RGDP) & 1.95 & 0.10 & 19.39 & 0.00 \\
C & -11.62 & 0.88 & -13.15 & 0.00 \\
R-squared & 0.93 & Mean dependent var & & 5.39 \\
Adjusted R-squared & 0.93 & S.D. dependent var & & 0.73 \\
S.E. of regression & 0.18 & Sum squared resid & & 0.78 \\
Durbin-Watson stat & 1.21 & J-statistic & & 0.01 \\
\hline
\end{tabular}

Table 5.4. Dependent variable - real non-tax revenues (RNONTAX)

\begin{tabular}{lllll}
\hline Variable & Coefficient & Std. Error & t-Statistic & Prob. \\
\hline LOG(RGDP) & 1.12 & 0.11 & 9.69 & 0.00 \\
C & -3.24 & 1.00 & -3.24 & 0.00 \\
R-squared & 0.84 & Mean dependent var & & 6.55 \\
Adjusted R-squared & 0.83 & S.D. dependent var & & 0.43 \\
S.E. of regression & 0.17 & Sum squared resid & & 0.68 \\
Durbin-Watson stat & 0.68 & J-statistic & & 0.06 \\
\hline
\end{tabular}

Table 5.5. Dependent variable - real taxes on domestic transactions (RTDT)

\begin{tabular}{lllll}
\hline Variable & Coefficient & Std. Error & t-Statistic & Prob. \\
\hline LOG(RGDP) & 2.68 & 0.18 & 14.76 & 0.00 \\
C & -17.04 & 1.61 & -10.58 & 0.00 \\
R-squared & 0.96 & Mean dependent var & & 6.27 \\
Adjusted R-squared & 0.96 & S.D. dependent var & & 1.05 \\
S.E. of regression & 0.20 & Sum squared resid & & 0.94 \\
Durbin-Watson stat & 0.26 & J-statistic & & 0.04 \\
\hline
\end{tabular}

Table 5.6. Dependent variable - real foreign trade taxes (RFTT)

\begin{tabular}{lllll}
\hline Variable & Coefficient & Std. Error & t-Statistic & Prob. \\
\hline LOG(RGDP) & 0.29 & 0.09 & 3.16 & 0.00 \\
C & 3.00 & 0.82 & 3.65 & 0.00 \\
R-squared & 0.32 & Mean dependent var & & 5.48 \\
Adjusted R-squared & 0.29 & S.D. dependent var & & 0.31 \\
S.E. of regression & 0.26 & Sum squared resid & & 1.50 \\
Durbin-Watson stat & 0.49 & J-statistic & & 0.05 \\
\hline
\end{tabular}

The GOJ, therefore, has two alternatives to reduce the budget deficit to acceptable rates. One technique is to reduce governmental expenditures, especially the current expenditures, so long as the role of government in funding productive and infrastructure projects and the welfare of people are not jeopardized. Another technique is to increase revenues independently of the real GDP. This change can be achieved by enhancing tax collection methods or/and reducing the rates of tax evasion or/and increasing non-tax revenues. More importantly, revenues must be used efficiently by being directed to productive public projects that help to increase growth rates as opposed to financing current spending. This process would add to the government's revenues and its ability to create more jobs. The success of the proposed alternatives to increase governmental revenues will necessarily affect the government's tendency to spend more. Thus, this study attempts to analyze the relationship between current and capital expenditures in one side and local and foreign revenues on the other side. Formulas (11) and (12) measure the elasticity of real current expenditures (RCURG) and real capital expenditures (RCAPG) with respect to real domestic revenues (RLREV) and real foreign grants (RFG).

$$
\begin{aligned}
& \log R C U R G=\alpha 0+\alpha 1 \log R L R E V+\alpha 2 \log R F G \\
& \log R C A P G=\alpha 0+\alpha 1 \log R L R E V+\alpha 2 \log R F G
\end{aligned}
$$

Tables 6.1 and 6.2 show the estimation results of formulas (11) and (12). The results in Table 6.1 show that the elasticity of current expenditures with respect to both local revenues and foreign grants are positive but its 
responsiveness to local revenues is higher. This fact may indicate that the government depends on local revenues more than foreign sources to operate its local economy, with a minimum dependence on external sources. However, this situation depends on the ability of local revenues to cover the increasing current expenditures and on the value of the current deficit. Table 6.2 reveals that foreign grants have no significant impact on capital expenditures; the elasticity of capital expenditures with respect to local revenues is, as expected, positive and low. This finding is logical because local revenues are mainly used to finance current expenditures in an attempt to reduce the current deficit. But, it is important to note that most foreign grants are supposed to be conditional on being spent in certain areas, keeping in mind that foreign aid is typically accompanied by political pressure from donors. Depending on foreign aid implies that governmental investments will heavily depend on foreign grants, which affect their sustainability and long-term impact. For example, in 2009 the CBJ reported shrinkage of foreign aids and grants as a result of the global financial and economic crisis, which in turn had a negative impact on governmental expenditures and deficits (CBJ, 2009). In conclusion, the efficient use of governmental revenues is a must.

Table 6.1. Dependent variable - real current expenditures (RCURG)

\begin{tabular}{lllll}
\hline Variable & Coefficient & Std. Error & t-Statistic & Prob. \\
\hline LOG(GRANTS) & 0.34 & 0.16 & 2.04 & 0.05 \\
LOG(LOCREV) & 0.79 & 0.10 & 7.84 & 0.00 \\
C & -0.42 & 0.31 & -1.37 & 0.17 \\
R-squared & 0.96 & Mean dependent var & & 7.31 \\
Adjusted R-squared & 0.96 & S.D. dependent va & & 0.80 \\
S.E. of regression & 0.15 & Sum squared resid & & 0.64 \\
Durbin-Watson stat & 1.26 & J-statistic & 0.03 \\
\hline
\end{tabular}

Table 6.2. Dependent variable - real capital expenditures (RCAPG)

\begin{tabular}{lllll}
\hline Variable & Coefficient & Std. Error & t-Statistic & Prob. \\
\hline LOG(GRANTS) & 0.35 & 0.28 & 1.25 & 0.22 \\
LOG(LOCREV) & 0.30 & 0.15 & 1.93 & 0.06 \\
C & 1.90 & 0.76 & 2.47 & 0.01 \\
R-squared & 0.73 & Mean dependent var & & 6.15 \\
Adjusted R-squared & 0.71 & S.D. dependent var & & 0.50 \\
S.E. of regression & 0.27 & Sum squared resid & & 2.08 \\
Durbin-Watson stat & 0.95 & J-statistic & & 0.03 \\
\hline
\end{tabular}

\section{Results and Recommendations}

While the applicability of Wagner's Law has been examined in both developed and developing countries, no studies have been recently conducted on this subject in Jordan. More importantly, while it is important to study how GDP growth affects governmental expenditures (the applicability of Wagner's Law), it is critical to examine the impact of GDP growth on governmental revenues. Furthermore, a clearer analysis requires examining the impact of GDP on the individual components of governmental expenditures and the components of governmental revenues. With these analyses, a comprehensive diagnosis can be achieved. We found that the elasticity of the real expenditures with respect to the real GDP is positive and greater than 1, which indicates the validity of Wagner's Law in the case of real governmental expenditures and its components. Furthermore, real current expenditures had the highest elasticity, indicating that its responsiveness to real GDP is greater than that of real capital expenditures. These results increase the burden on the government since more revenues become urgently needed. We also found that the elasticity of real total governmental revenues and grants are positive and greater than 1, but less than the elasticity of governmental revenues. However, the elasticity of the real local revenues, the real income tax revenues, and the real taxes on domestic transactions are all positive and greater than one. The highest elasticity corresponds to real taxes on domestic transactions (sales tax), followed by that of real income tax and finally that of real non-tax revenues. Interestingly, we found that the elasticity of real foreign trade revenues is, while positive, too low and much less than one. This fact explains the relatively low value of the elasticity of real total governmental revenues with respect to real GDP since real foreign trade taxes represent a major part of local revenues. We propose two applicable alternatives to reduce the budget deficit to acceptable rates. One technique is to compress governmental expenditures, especially the current expenditures, so long as the role of the government in funding productive and infrastructure projects and the welfare of people are not jeopardized. Another technique 
is to increase revenues independently of real GDP. This goal can be achieved by enhancing tax collection methods or/and reducing the rates of tax evasion or/and increasing non-tax revenues. More importantly, revenues must be used efficiently by directing them toward productive projects rather than financing current expenditures. This process adds to governmental revenues and the government's ability to create more jobs. The success of the proposed alternatives to increase governmental revenues will necessarily affect the government's tendency to spend more. In this regard, we show that the elasticity of both the real current expenditures with respect to local and foreign revenues is positive and significant. However, the responsiveness of the real current expenditures is much higher, which indicates the government's tendency to use its domestic revenues to operate its local economy with a minimum dependence on external sources. More importantly, we found that foreign grants are mainly used to fund capital expenditures, which is shown from the positive but insignificant significant elasticity of the former with respect to the latter. This fact can be understood from the fact that most foreign grants are conditional on being spent in certain areas, keeping in mind that foreign aid is typically accompanied by political pressure from donors. This situation also implies that governmental investments strongly depend on foreign grants that affect their sustainability and long-term impact. Accordingly, recent local, regional, and international events have impacted the governmental budget deficit in Jordan. Significant research efforts must be directed to the public finance sector in an attempt to solve its structure imbalances and deficits.

\section{References}

Afzal, M. (2009). Population Growth and Economic Development in Pakistan. Open Demography Journal, 2, 17. http://dx.doi.org/10.2174/1874918600902010001

Afzal, M., \& Abbas, Q. (2010). Wagner's law in Pakistan: Another look. Journal of Economics and International Finance, 2(1), 12-19.

Akitoby, B., Clements, B., Gupta, S., \& Inchauste, G. (2006). Public spending, voracity, and Wagner's law in developing countries. European Journal of Political Economy, 22(4), 908-924. http://dx.doi.org/10.1016/j.ejpoleco.2005.12.001

Anwar, M. S., Davies, S., \& Sampath, R. K. (1996). Causality between Government expenditures and Economic Growth: An Examination Using Cointegration Techniques. Public Finance, 51(2), 166-184.

Bohl, M. T. (1996). Some International Evidence on Wagner's law. Public Finance, 51(2), 185-200.

Case, K. E., \& Fair, R. C. (2008). Principles of Macroeconomics (7th ed.). USA: Prentice Hall.

Central Bank of Jordan. (2009). Annual Report, Amman, Jordan.

Central Bank of Jordan. (2010). Annual Report, Amman, Jordan.

Chletsos, M., \&, Kollias, C. (1997). Testing Wagner's Law Using Disaggregated Public Expenditure Data in the Case of Greece: 1958-1993. Applied Economics, 29(3), 371-377. http://dx.doi.org/10.1080/000368497327155

Courakis, A. S., Moura-Roque, F., \& Tridimas, G. (1993). Public expenditure growth in Greece and Portugal. Wagner's Law and beyond. Applied Economics, 25(1), 125-134. http://dx.doi.org/10.1080/00036849300000121

Dritsakis, N., \& Adamopoulos, A. (2004). A causal relationship between government spending and economic development: an empirical examination of the Greek economy. Applied Economics, 36(5), 457-464. http://dx.doi.org/10.1080/00036840410001682151

Gandhi, V. P. (1971). Wagner's Law of Public Expenditure: Do Recent Cross-Section Studies confirm it? Public Finance, 26(1), 44-56.

Goffman, I. J. (1968). On the Empirical Testing of Wagner's Law: A Technical Note. Public Finance, 23(3), 359-364.

Gordon, R. J. (2006). Macroeconomics (10th ed.). USA: Addison Wesley.

Gupta, S. P. (1967). Public Expenditure and Economic Growth: A Time Series Analysis. Public Finance, 22(4), 423-461.

Gyles, A. F. (1991). A Time-Domain Transfer Function Model of Wagner's Law: The Case of the United Kingdom Economy. Applied Economics, 23, 327-330. http://dx.doi.org/10.1080/00036849100000140

Henrekson, M. (1993). Wagner's Law - A Spurious Relationship? Public Finance, 48(2), 406-415.

Khan, A. H. (1990). Wagner's 'Law' and the Developing Economy: A Time Series Evidence from Pakistan. The 
Indian Journal of Economics, 38(1), 115-123.

Magableh, I. (2009a). Economics of Microfinance and SMEs in Jordan. VDM Verlag Dr. Muller Aktiengesellschaft \& Co. KG.

Magableh, I. (2009b). The Role of Micro, Small and Medium Enterprises (MSME) in the Fight against Unemployment in the Arab Countries. ALO.

Magableh, I., Athamneh, A., \& Almahrouq, M. (2010). The Economic Impact of Inbound and Outbound Labor Immigration: The Case of Jordan (1970-2006). The International Journal of Development Issues, 9(1), $53-$ 67. http://dx.doi.org/10.1108/14468951011033806

Mohsin, K. S. B., \& Kamaiah, B. (1992). Causality between Public Spending and National Income in India. Asian Economic Review, 54(2), 375-390.

Murthy, V. N. R. (1993). Further Evidences of Wagner's Law for Mexico: An Application of Cointegration Analysis. Public Finance, 48(1), 92-96.

Musgrave, R. A. (1969). Fiscal Systems New Haven and London. Yale University Press.

Nomura, M. (1995). Wagner's Hypothesis and Displacement Effect in Japan, 1960-1991. Public Finance, 50(1), $121-135$.

Oxley, L. (1994). Cointegration, Causality and Wagner's Law: a Test for Britain 1870-1913. Scottish Journal of Political Economy, 41(3), 286-298. http://dx.doi.org/10.1111/j.1467-9485.1994.tb01127.x

Park, W. K. (1996). Wagner's Law vs. Keynesian Paradigm: The Korean Experience. Public Finance, 51(1), $71-$ 91.

Peacock, A. T., \& Wiseman, J. (1961). The Growth of Public Expenditure in the United Kingdom. Cambridge, UK: NBER and Princeton: Princeton University Press.

Pryor, F. L. (1968). Public Expenditure in Communist and Capitalist Nations. London: George Allen and Unwin.

Ram, R. (1987). Wagner's hypothesis in time series and cross section perspectives: evidence from 'Real' data for 115 countries. Review of Economics and Statistics, 69(2), 359-393. http://dx.doi.org/10.2307/1927226

Sztbyer, W. B. (2001). Market and State in Globalization. European Journal of Law and Economics, 12, 145150. http://dx.doi.org/10.1023/A:1012594418958

Talafha, H., Iqbal, A., \& Siddiqi, M. W. (2010). Growth, Population, Exports and Wagner's Law: A Case Study of Pakistan (1972-2007). International Journal of Human and Social Sciences, 5(5), 332-338.

Verma, S., \& Arora, R. (2010). Does the Indian Economy Support Wagner's Law? An Econometric Analysis. Eurasian Journal of Business and Economics, 3(5), 77-91.

\section{Copyrights}

Copyright for this article is retained by the author(s), with first publication rights granted to the journal.

This is an open-access article distributed under the terms and conditions of the Creative Commons Attribution license (http://creativecommons.org/licenses/by/3.0/). 